\title{
MILITARY JUSTICE: A NEW ATTEMPT TO ADVANCE INDIVIDUAL RIGHTS
}

$\mathbf{T}_{\text {he Uniform Code of Military Justice }}{ }^{\text {provides in article }} 38(\mathrm{~b})^{2}$ that an accused in a general or special court-martial may be represented in his defense by civilian counsel if provided by him, military counsel of his own selection if reasonably available, or military defense counsel appointed in his behalf pursuant to article $27 .^{3}$ In so far as general courtsmartial are concerned, it is clear that only qualified lawyers may appear as either civilian ${ }^{4}$ or appointed counsel. "Military counsel," however, have characteristically been neither licensed nor trained to practice law, a usage to which most military personnel have become conditioned in the belief that service as counsel is but another duty of the commissioned officer. ${ }^{6}$ In the recent case of United States v. Kraskouskas, ${ }^{7}$ the United

${ }^{1}$ ro U.S.C. §§ 80r-940 (Supp. V, 1958).

${ }^{2}$ ro U.S.C. $\$ 838$ (Supp. V, r 9.58 ).

${ }^{8}$ xo U.S.C. $\$ 827$ (Supp. V, 1958).

United States v. Gudobba, A.C.M. I1220, 20 C.M.R. 864, 868 (1955); United States v. Kraskouskas, 9 U.S.C.M.A. 607, 609, 26 C.M.R. 387,389 (1958) (dictum). In United States v. Moore, A.C.M. 473I, 4 C.M.R. 586 (1951), in addition to the regularly appointed defense counsel, the accused was allowed to have civilian counsel who was not a member of an American bar, but, rather, was a qualified Japanese lawyer.

${ }^{5}$ 10 U.S.C. $\$ 827$ (Supp. V, 1958). See note 13 infra.

- The first reference to alyy right of the accused to counsel is found in a War Department general order published in 1890 , which required that commanders of posts where courts-martial were convened detail, if possible, and if requested by the accused, a suitable officer as his counsel. See Kelly, Uniform Code and the Evolution of Military Law, 22 U. CINC. L. REv. 343,348 (1953). In 1916 the manual for courts-martial was published containing the first provision assuring the accused of the right to be represented by counsel. It contained the qualification, however, that officers of the Judge Advocate General's Department were not available for appointment as counsel for the defense in trials by court-martial. U.S. DEP'T OF ARMY, MANUAL FOR CourtsMartial, UNited States para. 108 (1917). The manual was amended in 1919, however, to provide that each court should appoint a defense counsel and that all accused persons could avail thenselves of his services if they desired. The annendment further provided that officers so detailed should be selected with the same care and have the same qualifications as officers of the Judge Advocate General's Corps. U.S. DEP'T oF ARMY, Manual for Courts-Martial, United States para, 107 (1921).

The first of a series of federal court cases which considered the question whether officers who served as counsel before courts-martial must satisfy the saine professionaltechnical requirements as counsel in civilian court cases was Romero v. Squier, 133 F.2d 528 (9th Cir. 1943). It was there held that an Army officer chosen by the accused and admitted by a court-inartial to practice did not also need to be admitted to practice be- 
States Court of Military Appeals, over a vigorous dissent, ${ }^{8}$ held that military counsel selected by the accused in a general court-martial may not be a nonlawyer. ${ }^{9}$

fore a civilian court. Cases which followed this precedent were: Altmayer v. Sanford, I48 F.2d I6I (5th Cir. 1945); Duval v. Humphrey, 83 F. Supp. 457 (M.D. Pa. 1949); Hayes v. Hunter, 83 F. Supp. 940 (D. Kan. 1948); Adams v. Hiatt, 79 F. Supp. 433 (M.D. Pa. 1948); Ex parte Steel, 79 F. Supp. 428 (M.D. Pa. 1948).

In 1948 Congress manifested an awareness of the necessity for increased protection of the accused, providing in the Articles of War that defense counsel appointed in general courts-martial were required to have the same legal qualifications as trial counsel. ART. WAR II of 1948,62 Stat. 759 (1948). This was a significant addition to the law, for it iusured the accused of equal representation if he chose to avail himself of it.

The most recent major statutory enactment on military law is the Uniform Code of Military Justice, effective in $195 \mathrm{I}$. It provides that defense counsel appointed by the convening authority to defend the accused in a general court-martial must be a lawyer. Art. 27 (b) (I). See note 13 infra.

The question whether an officer who was not a qualified lawyer could represent the accused before a general court-martial, in lieu of the court-appointed counsel was raised before the United States Court of Military Appeals three times in 1952. In each case it was decided that prejudice to the accused could not be inferred solely from the fact that the prosecutor was legally trained while the defense counsel was not. United States v. Hunter, 2 U.S.C.M.A. 37, 6 C.M.R. 37 (1952); United States v. Phillips, I U.S.C.M.A. 316,3 C.M.R. 50 (1952); United States v. Bartholomew, I U.S.C.M.A. 307, 3 C.M.R. 4 I (1952).

${ }_{9}$ U.S.C.M.A. 607, 26 C.M.R. 387 (1958). Private Kraskouskas was charged with violation of several punitive articles of the Uniform Code of Military Justice. The convening authority appointed as defense counsel a qualified attorney who was an officer in the Judge Advocate General's Corps. At the same time, the accused requested and obtained the services of a nonlawyer as individual counsel. These officers prepared the case together, but when the case came up for trial before a general court-martial convened at Seoul, Korea, appointed counsel announced in court that the accused would be defended by individual counsel. Individual counsel had the court excuse the regularly appointed defense counsel.

${ }^{8}$ Judge Latimer reasoned that since the practice of allowing nonlawyers to represent the accused in military courts had been long established, some enactment showing clearly that Congress intended to change the law was required to justify the majority's position. He observed that the Code does not require individual counsel to be a qualified lawyer and that the opinion of the court is contrary to the Manual for Courts-Martial in this respect. Judge Latimer also disapproved of permitting a mentally competent person to obtain a reversal on the basis that he was given a privilege which he demanded. United States v. Kraskouskas, 9 U.S.C.M.A. 607, 613, 26 C.M.R. 387, 393 (1958).

'The question was raised again on the same day, in United States v. Davis, 9 U.S.C.M.A. 614, 26 C.M.R. 394 (1958), and was decided in accordance with the Kraskouskas case.

Since the United States Court of Military Appeals is the highest military court, its decisions are not appealable within the framework of the military court system. Neither are its decisions reviewable on direct appeal to a federal court. See United States v. Ferguson, 5 U.S.C.M.A. 68, 17 C.M.R. 68 (1954). Although decisions of the court 
The practice of permitting lay officers to represent defendants in general courts-martial had legal and practical justification. Legally, it has been thought that neither the Constitution ${ }^{10}$ nor congressional legislation ${ }^{11}$ guarantees representation by legally qualified counsel in court-martial proceedings. Practically, there has not regularly been within the military services a number of lawyers sufficient to provide all persons accused of crime with legally trained counsel. ${ }^{12}$

In addition to the settled previous practice, ${ }^{13}$ there were other factors in the instant case which aggregated to present the strongest possible in-

may be attacked collaterally in a federal court through the writ of habeas corpus, this remedy is available only to secure the release of a prisoner undergoing confinement. See United States v. Ferguson, supra; Note, Military Law-Due Process-Review of Courts-Martial on Petition for Habeas Corpus, 2 I Geo. WAsH. L. REv. 492 (1953).

${ }^{10}$ Altmayer v. Sanford, 148 F.2d 161 (5th Cir. 1945); Romero v. Squier, 133 F.2d 528 (9th Cir. 1943); Hayes v. Hunter, 83 F. Supp. 940 (D. Kan. 1948). See also Wiener, Courts-Martial and the Bill of Rights: The Original Practice I, 72 HARv. L. REv. I (1958).

${ }^{11}$ See the dissenting opinion of Latimer, J., in United States v. Kraskouskas, 9 U.S.C.M.A. 607, 611, 26 C.M.R. 387,391 (1958). See also United States v. Bartholomew, 1 U.S.C.M.A. 307, 3 C.M.R. 41 (1952).

${ }^{12}$ See Hayes v. Hunter, $8_{3}$ F. Supp. 940 (D. Kan. 1948); United States v. Hunter, 2 U.S.C.M.A. 37,6 C.M.R. 37 (1952).

${ }^{13}$ Not only was representation by nonlegal military counsel entrenched in accepted usage, it is also sanctioned by rather clear inference from paragraph 6 if of the Manual for Courts-Martial, which is based upon the mandatory provision of article 27 of the Uniform Code of Military Justice.

Article 27 requires the convening authority to appoint counsel for the accused in each general and special court-martial and provides specifically that trial counsel and defense counsel detailed for a general court-marital "( 1 ) shall be a judge advocate of the Army or the Air Force or a law specialist of the Navy or Coast Guard, who is a graduate of an accredited law school or is a member of the bar of a Federal Court or of the highest court of a state; or shall be a member of the bar of a Federal Court or of the highest court of a state; and (2) shall be certified as competent to perform such duties by the Judge Advocate General of the armed force of which he is a member." Although article 27 is silent upon the qualifications of individually selected counsel, paragraph $61 \mathrm{f}$ of the Manual for Courts-Martial provides in part that "in a trial by general court-martial, should the accused be represented by counsel of his owm selection who is not qualified to act as counsel before a general court-martial, the accused should be advised that he is entitled to be represented by counsel who is qualified to act as counsel before a general court-martial." This passage would be completely superfluous if individually selected counsel were required to be qualified lawyers, especially in view of a subsequent provision of paragraph $6 \mathrm{if}$ which states that when the accused elects to be represented by individually chosen counsel, regardless of that counsel's legal qualifications, the duly appointed defense counsel shall, if the accused so desires, act as associate counsel; otherwise he shall be excused. See the dissenting opinion of Latimer, J, in I'nited States v. Kraskouskas, 9 U.S.C.M.A. 607, 6I1, 26 C.M.R. 387,391 (1958). 
ducement for affirming the conviction: The accused purposefully rejected the services of appointed counsel, choosing instead to be represented by military counsel without formal legal training, and it was evidently conceded that this officer conducted the defense in a skillful manner. ${ }^{14}$ Thus, if there was error, it was self-induced and not clearly prejudicial. Yet, the court reversed conviction and precedent alike, saying, "... we believe that the day in which the nonlawyer may practice law before a general court-martial must draw to an end. $\$ 15$

This bold and retrospective injection of a new tenet into military law at least ostensibly represents an obvious and logical step in the pronounced current trend toward approximating the standard for protection of individual rights in the application of military justice to that recognized in civilian courts. ${ }^{16}$ The court sought to insulate the administra-

"The court pointed out that individual counsel, among other things, exercised a challenge against a court member, offered several motions for appropriate relief with legal argument in support thereof, moved to dismiss one specification on the grounds of failure to allege an offense and another specification on the ground of unreasonable multiplication of charges, made numerous and timely objections to trial counsel's examination of the witnesses and to the introduction of evidence, made closing arguments on findings, and requested instructions favorable to the accused. Moreover, the accused was acquitted of two of the four charges against him. 9 U.S.C.M.A. 607, 608, 26 C.M.R. $3^{8} 7,388$ (1958).

${ }^{26} 9$ U.S.C.M.A. $607,609,26$ C.M.R. 387,389 (1958).

${ }^{16}$ This trend, born in the widespread discussion and criticism of the court-martial system following World War II, led to the establishment of the Uniform Code of Military Justice in $195 \mathrm{x}$. The Code advanced the broad concept of individual rights by providing the accused with significant new safeguards: the requirement of extensive pre-trial investigations, the right of an enlisted man to have other enlisted persons on the court that sits in judgment of him, the provision for automatic review of the trial record, and the furnishing of legally qualified counsel to the accused. The Code also sought to effect a workable compromise between the paramount need for maintaining military discipline and the need for protection of individual rights against the arbitrary effects of "command influence." Furthermore, it established a bipartite courtmartial, nearly duplicating the pattern of civilian courts, composed of law officer (judge) and court members (jury). Perhaps most significantly, the 195 I Code established the United States Court of Military Appeals, a civilian court, insulated from command influence at the top of the military hierarchy. U.C.M.J. arts. 16,25 (c), 27 (b) $, 32,37,60,61,67$, 10 U.S.C. $\$ \S 816,825,827,832,847,860,861,867$ (Supp. $V$, 1958). See Everett, Military JUstice in the ARMEd Forces of the UNited States 8-16 (ist ed. 1956).

In furthering the spirit of the Code, the court, from the outset, has acted as a catalyst in the new trend by establishing an advanced concept of military due process, limiting command influence on courts-martial, defining the law officer's role under the Code, and creating a solid decisional framework for the day-to-day administration of military justice. See, e.g., United States v. Walters, 4 U.S.C.M.A. 617,16 C.M.R. 191 (1954); United States v. Knudson, 4 U.S.C.M.A. 587, 16 C.M.R. 161 (1954); 
tion of military justice against unethical practitioners and to safeguard the accused from the possibility of incompetent representation during court-martial proceedings, ${ }^{17}$ while at the same time allowing him to benefit from the service of nonlegal counsel in a purely advisory capacity. ${ }^{18}$ In most situations, the decision will probably conduce a desirable result, since an accused may still elect representation by civilian counsel, ${ }^{19}$ by qualified military counsel from another command, ${ }^{20}$ or by himself. ${ }^{21}$

It should be recognized, however, that the freedom of an accused to employ civilian counsel may, in reality, be seriously limited by the relatively high cost of their services, their scarcity in certain remote commands, and their possible unfamiliarity with the courts-martial system. Similarly, the right of an accused to draw qualified military counsel from another command is liable to be meaningless in view of the other demands upon the time of such persons and the possible unwillingness of their commands to release them for this purpose.

Thus, it requires no stretching of the imagination to conceive a situation in which the Kraskouskas rule will present an accused with an election between only two real alternatives-self-representation or representation by appointed counsel. ${ }^{22}$ In such a circumstance there may be valid reasons for the accused to prefer to select nonlegal military

Walker, An Evaluation of the United States Court of Military Appeals, 48 Nw. U.L. Rev. 714 (1954); Wurfel, Military Due Process: What Is It?, 6 VAND. L. REv. 25 (1953); Note, Judicial Checks on Command Influence under the Uniform Code of Military Justice, 63 YALE L.J. 880 (1954); Jones, Changing Concepts in the Administration of Military Justice, Army Magazine, July 1958, vol. 8, pp. 46-50.

${ }^{27} 9$ U.S.C.M.A. 607, 609, 610, 26 C.M.R. $387,389,390$ (1958).

${ }^{28} \mathrm{Id}$. at $6 \mathrm{ro}, 26$ C.M.R. at 390 . Query, however, whether a line officer will customarily be released by his commanding officer merely to sit in on an accused's trial in an advisory capacity.

${ }^{10}$ U.C.M.J. art. $3^{8(b)}$, ro U.S.C. $\$ 88_{3} 8$ (Supp. V, 1958).

${ }^{20}$ Ibid. Sec note 22 infra.

${ }^{21}$ United States v. Kraskouskas, 9 U.S.C.M.A. 607, 610, 26 C.M.R. 387,390 (1958); Adams v. United States, 317 U.S. 269 (1942).

${ }_{22}$ Other possibilities of but questionable significance are: The accused may have the opportunity to select as defense counsel a legal officer in the J.A.G. section from his own command other than the one appointed in his behalf, or a line officer who is a qualified lawyer, if such an officer is available and is willing to defend the accused. An enlisted man who is a qualified lawyer may also represent the accused in a special court-martial, provided that the accused has specifically requested his services in lieu of the regularly appointed defense counsel, and provided that such regularly appointed defense counsel is appointed as assistant defense counsel. In such a case the accused may accept or reject the appointed counsel as assistant defense counsel. United States v. Long, 5 U.S.C.M.A. 572 , 18 C.M.R. 196 (1955). 
counsel, as sanctioned by the old rule, a rule which in fact might better protect his individual rights. In addition to giving the accused a broader choice of counsel, thereby enhancing his chances of being represented by someone highly motivated in his behalf, the prior rule enabled an accused to select as counsel a line officer who might be better able to develop a rapport with the court, especially where a military crime was involved. In this regard, it is interesting to contrast the performance of the nonlegal counsel in the Krasbouskas case $\mathrm{e}^{23}$ with that of appointed counsel in another case ${ }^{24}$ considered by the Court of Appeals on the same day and reversed on the ground that appointed counsel's performance was so negligently and ineffectively rendered as to constitute a denial of due process. Of further significance to an accused is the possibility that a line officer might less likely be subject to "command influence" than would an appointed counsel, who is typically a staff member of the convening authority. ${ }^{25}$

The prior rule, while permitting wider latitude of choice, was subject to appellate review to insure the rendering of procedural due process. ${ }^{26}$ Whether the inflexible Kraskouskas standard, which presumably countenances similar review, will advantageously supplant its predecessor may never be known, since the facts pertinent to this question can be no more than the subject of conjecture in succeeding cases. But an analysis of the decision does suggest the inadvisability of propounding rules possibly ill-adapted to all circumstances existing in military installations flung far over the globe, especially when the subtle niceties of command influence may be involved. Moreover, it seems fair to question whether the decision manifests an awareness of the court of the burden which a substantial mobilization would cast upon the entire courts-martial system.

\footnotetext{
${ }^{23}$ See note 14 supra.

${ }^{26}$ United States v. Horne, 9 U.S.C.M.A. 601, 26 C.M.R. 381 (1958). See discussion of ineffective trial representation as ground for court-martial reversal in Military Justice: The United States Court of Military Appeals 29 November 19512030 June 1958, MilitaRy L. Rev. 67, 107-II5 (Dep't of Army Pamphlet No. 27-100-3, 1959).

${ }^{25}$ The commanding officer of the military establishment at which a court-martial is convened, although he is not the accuser, is usually the convening authority and as such appoints the law officer, trial counsel and defense counsel, and reviews the findings and sentence. The fact that a commanding officer controls the efficiency reports, assignments, promotions, and leaves of his staff members makes them particularly amenable to "command influence." See EVERETT, op. cit. supra note 16, at II-15. For suggested reforms, see Mugel, Military Jistice, Command and the Field Soldier, 2 Buffalo L. Rev. 183 (1953).

${ }^{\text {s6 }}$ See note 24 supra.
} 